\title{
ARAB-NORMAN HERITAGE: STATE OF KNOWLEDGE AND NEW ACTIONS AND INNOVATIVE PROPOSAL
}

\author{
R. Prescia ${ }^{a}$, A. Scianna ${ }^{b}$ \\ ${ }^{a}$ Università degli Studi di Palermo, Scuola Politecnica, Dipartimento di Architettura, Viale delle Scienze, Ed. 14, 90128 Palermo, Italia, \\ renata.prescia@unipa.it \\ b Università degli Studi di Palermo, Scuola Politecnica, GISLAB -ICAR CNR c/o D’Arch Viale delle Scienze, Ed. 8, 90128 Palermo,
} Italia, andrea.scianna@cnr.it

KEY WORDS: Arab-norman architecture, restoration, geomatics, cataloguing, data-base.

\begin{abstract}
:
This paper wants to offers a perlustrative recognition on the 'state of the studies', concerning to the Arab-Norman architecture of Palermo, admissed by Unesco in 2015 and explain a research in progress which, starting from re-cognition of the peculiarities of the restoration work carried out on it, consisting of the identification of authentic material-constructive values and / or reconstruction, it orients itself to develop a concrete proposal of filing for a more conscious knowledge. She, moreover, wants contribute to real enhancement through the use of targeted communication strategies that use innovative means capable, on one hand, to attracting the greatest possible number of users, on the other hand, to plan further interventions of conservation coherent with the previous data. The product that you want to achieve is that of a Bank-data that allows the "networking" of monumental emergencies, that become the virtual itineraries waypoint, which can be implemented periodically and whose boards meet the cataloging needs and documentation but with reference at geo-referred systems, compatible with the conservation and management of heritage and with need of usability, real and virtual.
\end{abstract}

\section{INTRODUCTION (R. Prescia)}

The recent admission UNESCO of Itinerary Arab-Norman of Palermo (Royal Palace, the Palatine Chapel and its treasure, the Church of St. John of the Hermits, the Church of St. Mary's, the church of San Cataldo, the Cathedral, Palazzo della Zisa and the adjoining Chapel, the Bridge of Admiral, the Cathedral of Cefalu and Monreale and the adjacent cloisters) raised the conservation and development programs for the monuments identified but also for others who, although belonging to the same historical period and with as many historical and monumental values, they were not able to enter for not adeguate conservation.

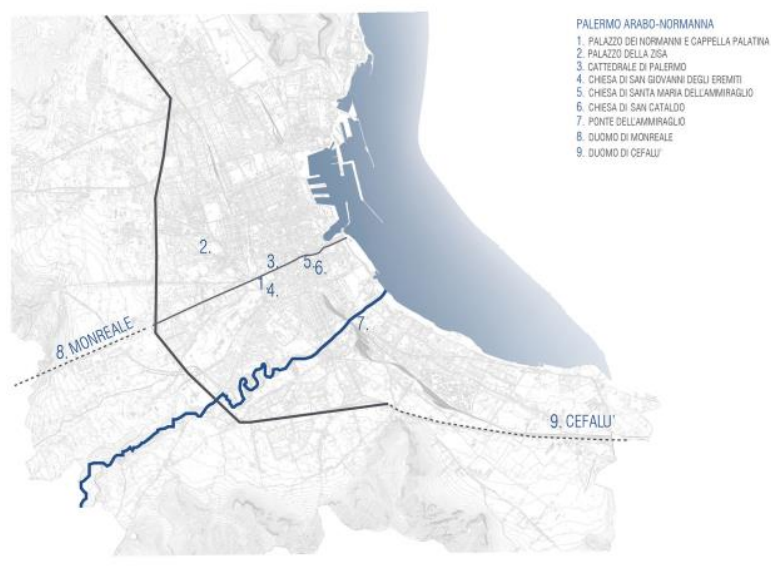

Figure 1. Location of UNESCO buildings.

If the 'state of the studies' traditional on these issues is very robust, in contrast to studies conducted according to the most digital technologies and reliefs processed with innovative instruments (total stations, laser scanners) but also databases that can be implemented periodically, it's still rares and not always meet the cataloging and documentation requirements in georeferiti-systems, compatible with the conservation and management of heritage and with need, real and virtual.

Moreover, the spread, fast and very quick, of the Digital Heritage has shifted the focus from concrete restoration programs in intangible enhancement programs aimed rather to evoke 'original states' which, though undoubtedly offer interesting contributions to the knowledge of our heritage, and, sometimes, anachronistic reconstructions prevent, however, have a limit of educating the nostalgia rather than to active conservation actions, which should however remain essential objective to be achieved for the protection.

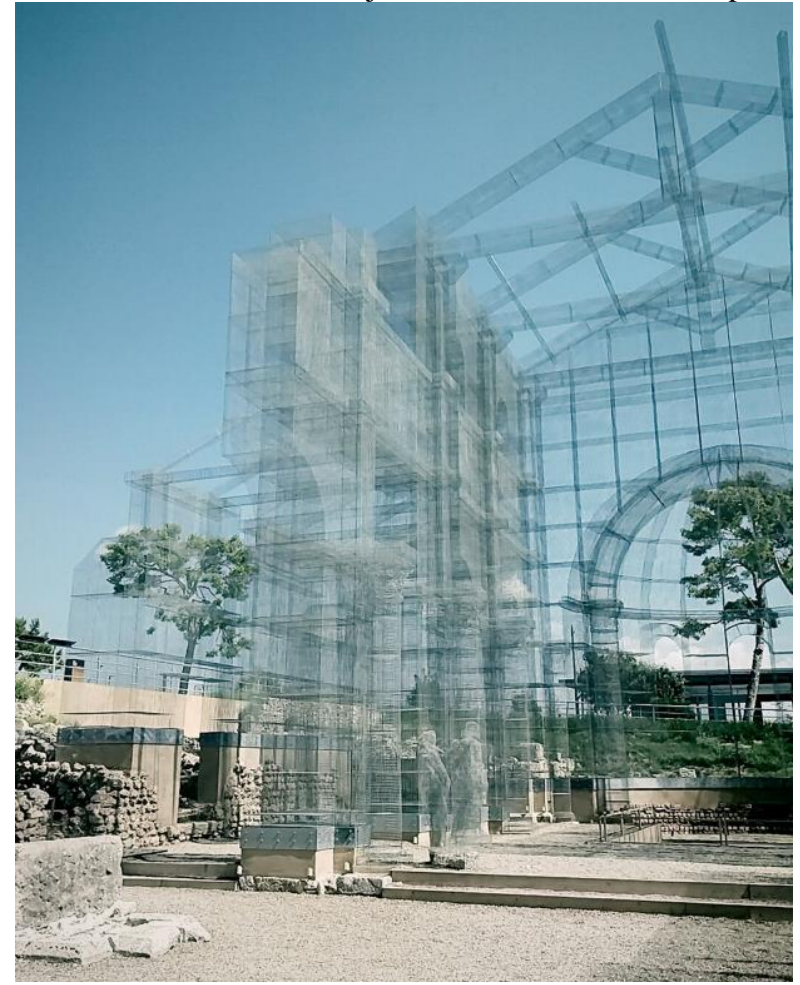

Figure 2. Evocative reconstruction of the Siponto Basilica, Tresoldi 2016 (ph. D. Russo) 
The documentation has a fundamental importance for the restoration because it testifies to the restoration carried out on a monument and, at the same, time retain the information about the conservation status of heritage that become necessary to enable periodic inspections and to realize actions necessary, according a culture of 'programmed preservation'. This importance has been acquired internationally with Carta for the interpretation and presentation of cultural heritage sites (ICOMOS 2008)

The re-cognition by the community in a more involved use of the 'cultural heritage' as $<<$ that complex of man's works in which a community recognizes its particular and specific values and with which it identifies > (Paper Krakow 2000), will certainly contribute to require these actions, too ignored by a short-sighted policy and, the other side, will fuel a higher quality of life and a cultural and economic growth of local communities.

\section{CURRENT STATUS AND PROPOSALS} (R. Prescia)

Recently, the field of Information and Communication Technology (ICT) is providing useful contributions to the wide wealth of cultural heritage as well as Geographic Information Systems (GIS) whose key features are those of 'geotag' the information, and therefore particularly useful for parts of the city, plus the ability to integrate disparate data while also allowing complex computations.

Despite the gradual spread of information technology, application to cultural heritage in Sicily is still not very common and, specifically, the Arab-Norman heritage does not enjoy of appropriately standardized information and georeferenced or of devices of augmented-reality.

The institution responsible for the protection of Sicily, a region with special status, became operational by Law 80 of 1977 and provided for the institution of the Regional Center for Cataloging and Documentation (CRICD) , ICCD national counterpart , charging to catalogue. The center has completed the digitization of existing paper scehde program in 2014 according to an information system Pa.Cu.S (Sicilian cultural heritage) which is now available on-line. An agreement signed in 2015 with the ICCD is allowing the transfer of the cards in SigecWeb national system; a winding way, determined by the 'autonomy' of Sicily that, in terms of cultural heritage, now seems incongruous and anachronistic, as well as exhausting (Lo Giudice, 2003). Even the parallel participation in the first phase of the national project ArtPast by the Superintendence was locked for similar reason. Moreover, the new catalogue it has been blocked with the attribution to those who had been the 'catalogers' from the experience of cultural deposits, with extensions on fixed-term contracts in the region, the office tasks. The CRICD has just launched the project School and communication for the promotion of UNESCO, in accordance with Law 77/06 Initiatives for Italian UNESCO sites (referent arch . G. Meli). www.CRICD.it

At present, and with reference of Arab-Norman architecture, on the site dell'Ass.to Reg.le BB.CC. you can only see a few videos that describe the history and restoration of a few, individual factories, without providing the user to interact with information and contribute collaboratively to the growth of the database and / or suggesting specific needs related to accessibility conditions or reporting of risk situations.

More targeted initiatives, such as the one put on by the Foundation Federico II, who runs the site of the Royal Palace in Palermo, where the seat of the Sicilian Regional Assembly, has merely provided a virtual tour of the monument that allows a mere exploration of environments without but no historical support; the Foundation's heritage UNESCO-Sicily, has produced a site (www.unescosicilia.it) where you can find information regarding the Arab-Norman itinerary application and cards on registered monuments. These, however, while providing data regarding the history and indicating the buffer-zone, are lacking in the communication of the material-constructive values, user and belonging.

By then treat the work done in the sense explicated in the introduction, we have to refer to an activity of scientific research, carried out between Institution and universities on specific projects and / or funding and on specific areas of land and / or monuments, he would need to be implemented and, above all applied and coordinated methodologically.

Central to this activity is absolutely the phase of the reliefs and their restitution in the drawing that remains, for architects, the main instrument of expression and, at the same time, the stretch of identity.

In the Arab-Norman architectures the only existing scientific reliefs are those conducted between 1977 and 1979 with topographic method and photogrammetric survey of the Cathedral of Cefalù (Prescia, 1988) and those, also computerized, between 1991 and 1993 on the Palatine Chapel and the Sala della Fontana in Zisa Palace (Monti, 1991, 1993) and, later, those with laser-scanners to the wooden ceiling of the Palatine Chapel, a restoration made possible by sponsors Wurth (Agnello, 2010), and one of the Tower Pisana in the Royal Palace for post-earthquake consolidation measures in 2002.

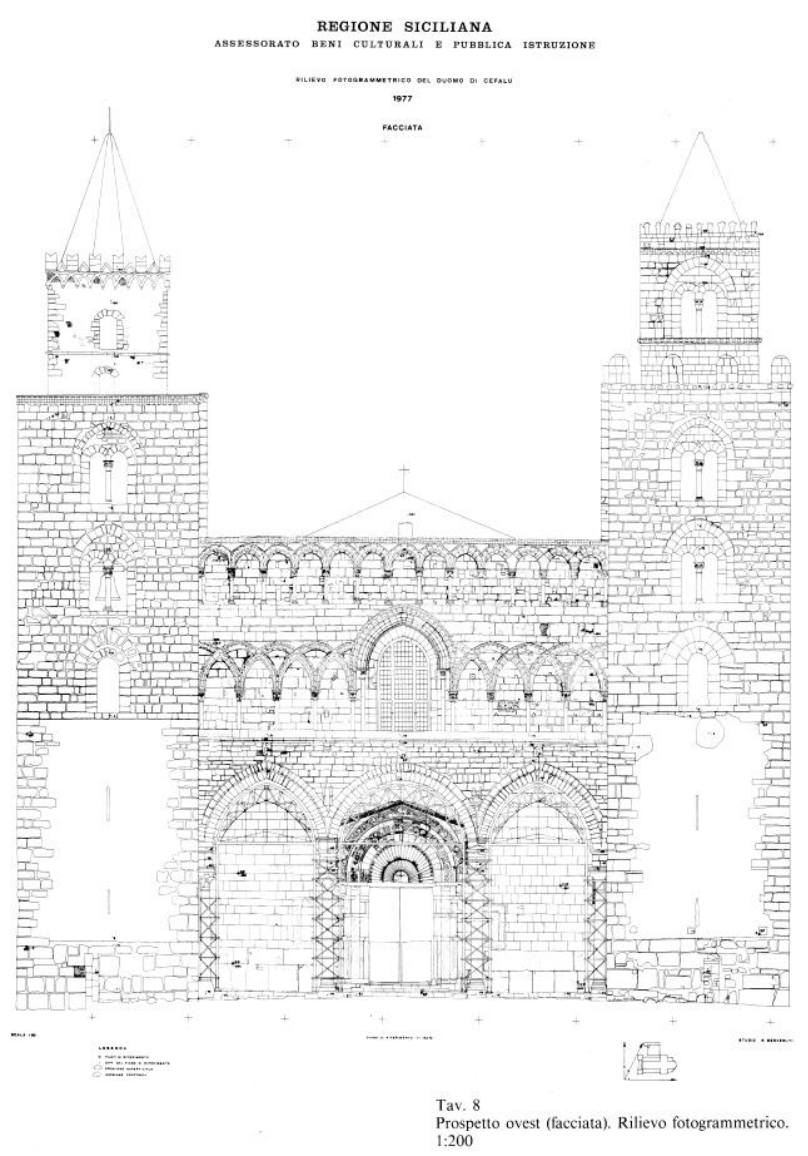

Figure 3. Photogrammetric restitution of 'Duomo di Cefalù' facade (Prescia, 1988) 


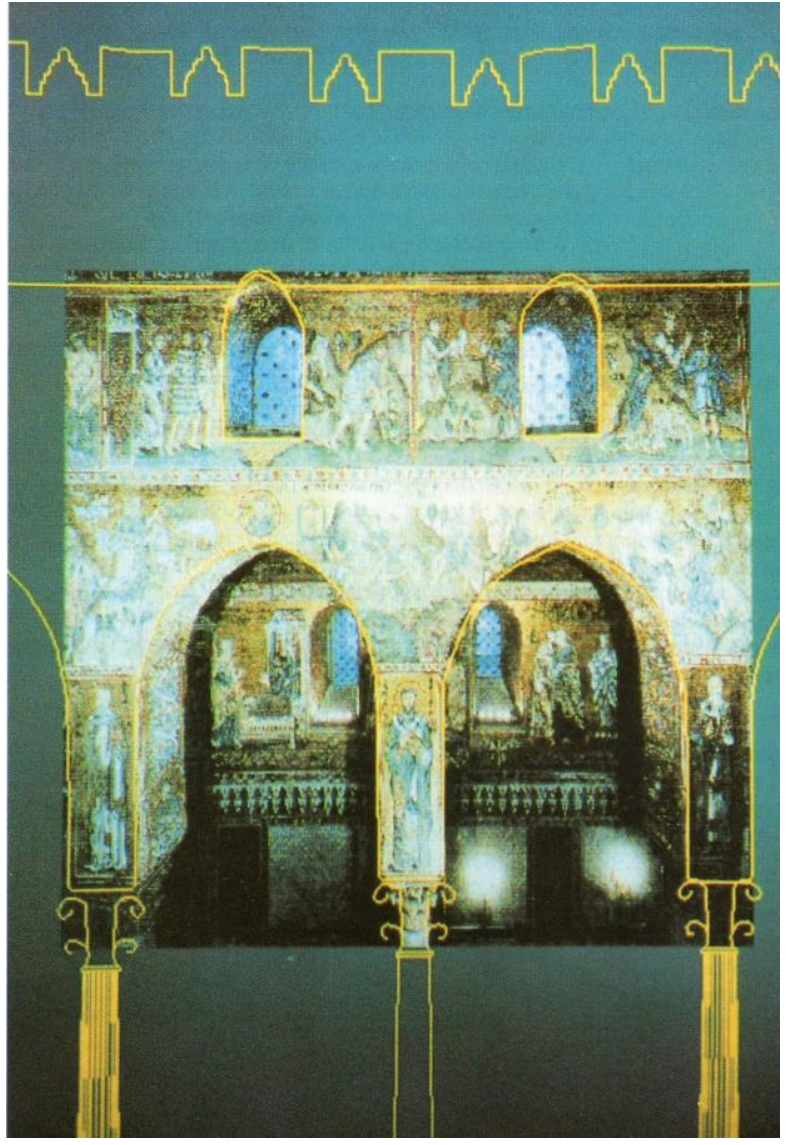

Figure 4. Interior of Palatine Chapel. Raster image with the surveyed profile (Monti, 1993)

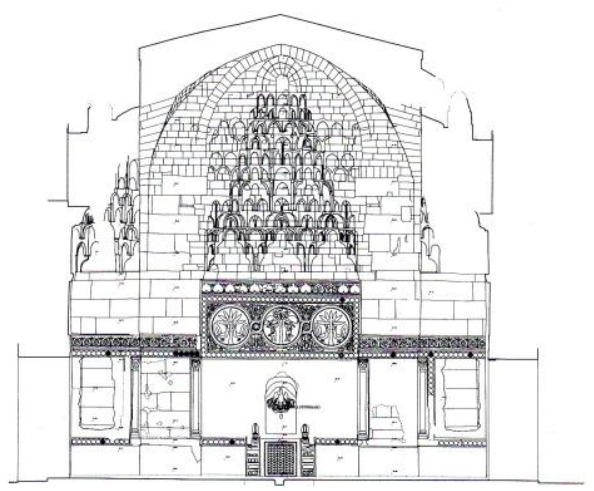

Figure 5. Hall of Fountain in the Zisa Palace (Monti, 1991).

But, in addition to the restoration, the reliefs are needed for the vast and ever present scope of 'communication', immaterial technological system that helps tell, disclose and transmit the material system (Prescia, 2004), and has become the first tool enhancement; to ensure that it is effectively requires close collaboration between experts in cultural heritage, experts in communication and information technology, web site ....

This is not always the case in these early years of great experimentation in which computer programming components went ahead quickly without connecting to the appropriate scientific skills and therefore you record many digitization processes, even sophisticated, but more inspired by a 'mediological model' that the real knowledge (Montella, Toscano 2010).
It thus constitutes a useful search path for those involved in restoration, identifying the most suitable ways to extract from all architectural peculiarities (values), proposing a widespread and innovative use, congealing around them the involvement of local communities in order to develop a process of identification, beginning by young people (Prescia, 2017).

That said, and always with reference of Arab-Norman architecture, you want to give this account of the research in progress, by the undersigned, conducted starting from the preparation of numerous degree to investigate and represent on the reliefs the restorations realized, between nineteenth-century and twentieth century, by Superintendents Giuseppe Patricolo and Francesco Valenti (Tomaselli, 1994; Genovese, 2010)

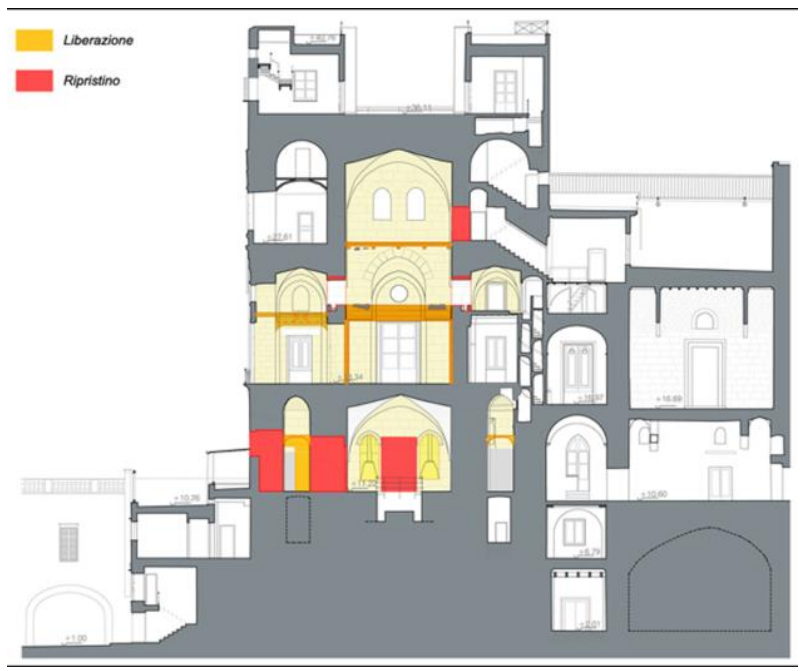

Figure 6. Restauration works in the Pisana Tower in Palermo by Francesco Valenti (Lucchese, 2012)

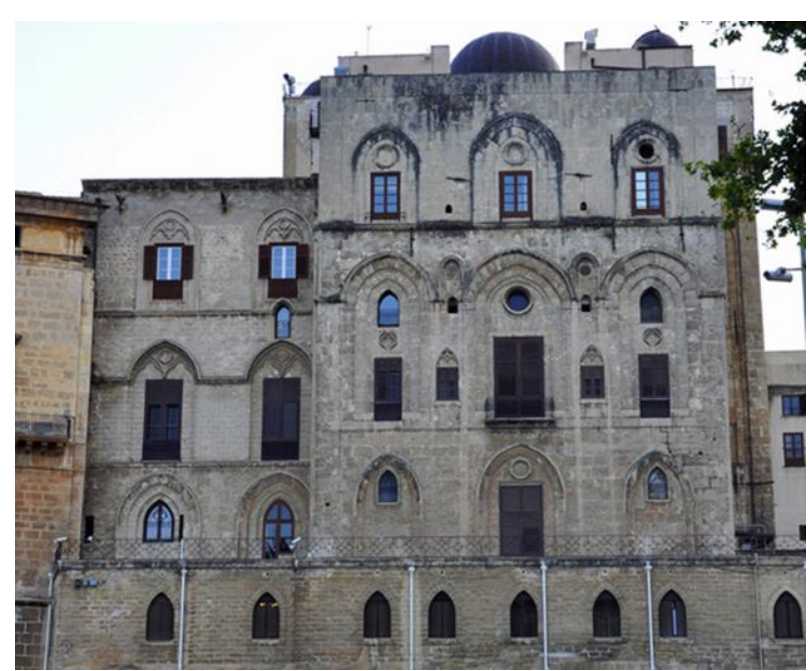

Figure 7. The Pisana Tower in Palermo (ph. R. Prescia)

The dissemination of such knowledge, at the time only heritage specialists, is an important finding for an authentic communication of monuments that make up much of the Sicilian identity so as to be largely been redone, demolishing successive layers, according to a restoration stylistics, as it was then in the culture. As well as those made after the bombing of World War II, the Superintendents Mario Guiotto, Armando Dillon and Giuseppe Giaccone 


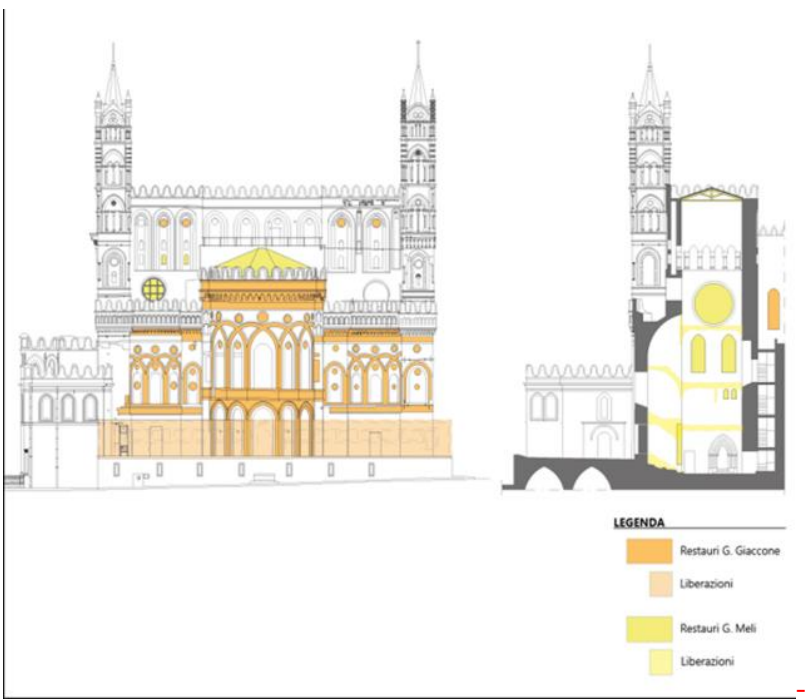

Figure 8. Restauri di Giaccone e più recenti (Bettina Fiore, 2012)

are important to document the intense post-bellica reconstruction, and determine the waste spectrum of 'reintegrazioni' (new integrations), even with the use of new materials, useful knowledge for future restorations.

This survey on the heritage of Palermo, during the insertion into a card-type to be included in a bank-data queried and updated, according to the procedures outlined in the following section. (Annex 1) (Trento, Zabbia, 2013)

An further research in progress it's the project Neptis (NEPTIS Project, 2013) that concerns the search for ICT solutions for the use and exploration-augmented of heritage and that you are putting in the work on the archaeological site the Eraclea Minoa and the three cathedrals of Palermo, Monreale and Cefalù.

The research team is interdisciplinary, including experts of cultural heritage, computer and GIS programmers, and the attempt is to drive digital technologies, which formed the core of the call, to achieve a quality of knowledge also building innovative viewpoints, respect albeit to a wide traditional knowledge, still it limited only to the historic-artistic elements. The group (Responsible: prof. Arch. Maria Luisa Germanà) of the Department of Architecture is involved in the drafting of reliefs, the history of restoration, knowledge of materials, communication and accessibility proposals on these monuments. The innovativeness of the research proposal currently, which it aims to create an app for tourist use of such sites, resides in covering such architectures as well as come down to us, in their complex layering, including artistic values and constructive values, and they understand them not merely as a work of art isolated and out of context, but inserted in the overall context original and current. (Prescia, 2015).

These architectures in fact are characterized by being part of the overall contexts: palaces Royal, cloisters, gardens in the case of cathedrals or thermae, 'peschiere', chapels in the case of 'sollazzi' that, in the transformations of modernity they were neglected, forgotten, in favor of the emerging architecture and therefore needs to recover fully understand the meaning of the settlements. In this sense, such data may be useful for the design of new enjoyment and communication processes to aim, rather than to the knowledge of their original configurations, which are very often compromised or lost, with the urban context, in order to put them back in the current socio-economic dynamics.

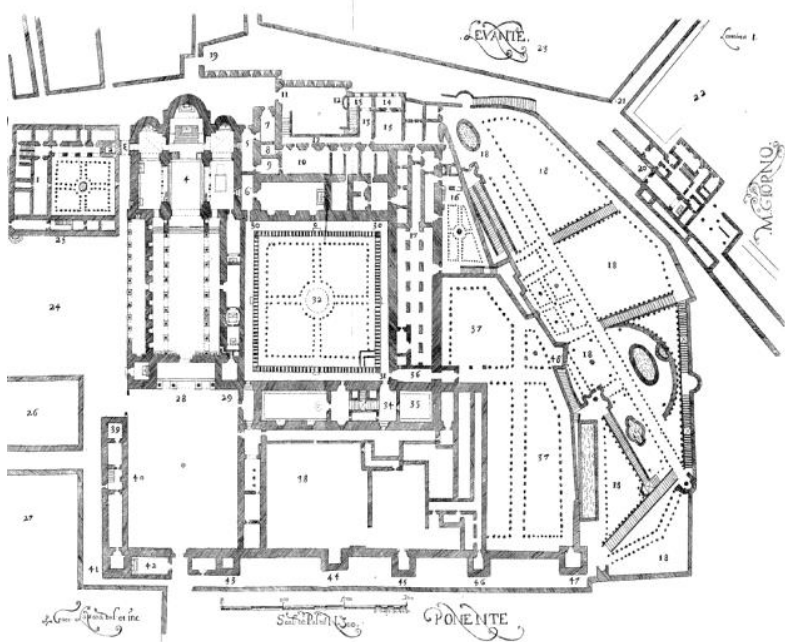

Figure 9. Map of monumental complex of Monreale (Del Giudice, 1702)

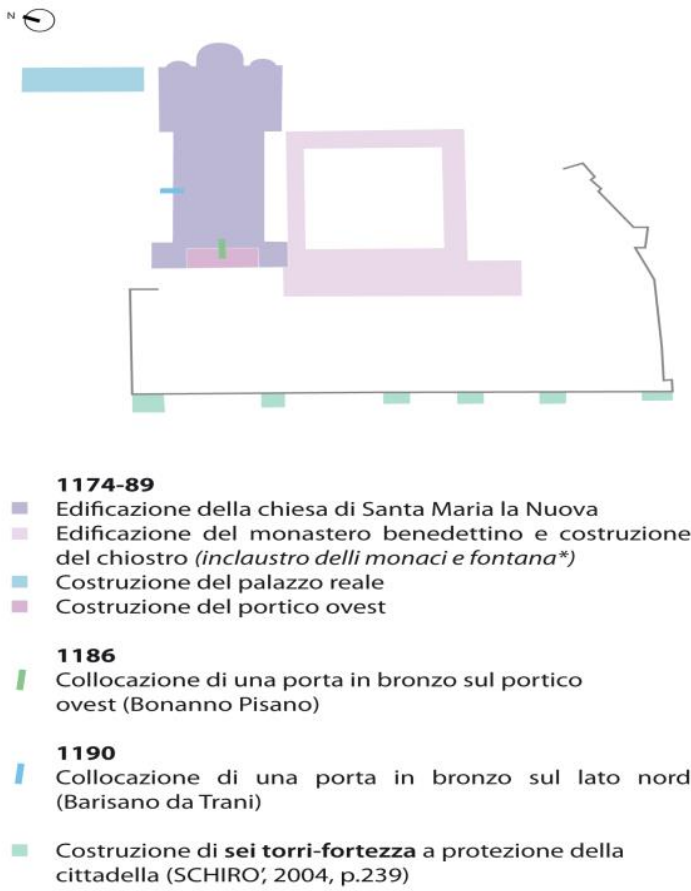

Figure 10. Original plant of Maredolce site (Di Franco, P. for Neptis Project)

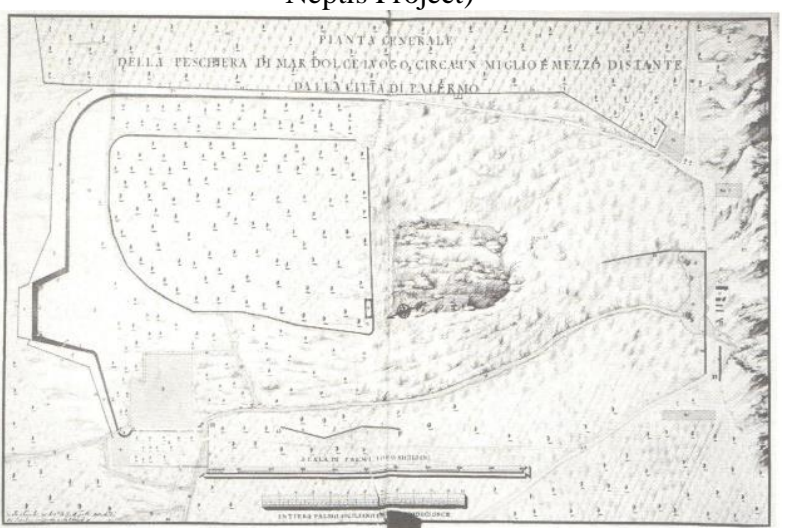

Figure 11. Map of Maredolce site (Chenchi, 1777) 
that, in the transformations of modernity they were neglected, forgotten, in favor of the emerging architecture and therefore needs to recover fully understand the meaning of the settlements. In this sense, such data may be useful for the design of new enjoyment and communication processes to aim, rather than to the knowledge of their original configurations, which are very often compromised or lost, with the urban context, in order to put them back in the current socio-economic dynamics.

This is, for eg., the case of Zisa Palace. Built by William I in 1165 and completed at the time of William II probably between 1175 and 1180, the Zisa palace stood near an aqueduct and a Roman bath. The complex was made up of a garden, and from a building on three levels with a rectangular plan; the rooms are arranged around the central hall with Iwan, whose fountain was connected to the outdoor 'peschiera' through a channel.

Used between the fourteenth and fifteenth century fortified farm house was transformed into a stately home in 1635 with the family of Sandoval, undergoing numerous changes. In 1951, he expropriated and handed over to the State Regional.

Following the North wing collapse, which occurred in 1971, it was started the works of the building restoration, which was completed in 1991. There was a lack, however, subsequent inheritance operations that could put links the building with the environment on which it stands and above with the elements that constitute the complex of the Norman 'sollazzo' (the chapel of SS. Trinity to Zisa, the 'peschiera', the 'gebbia'). Different properties have not, in fact, made possible a substantive dialogue between the parties, effectively excluding the possibility of using, and thus better understand, from a tourist, the whole of the 'sollazzo' system. It is' therefore desirable a project with a real connection, between old and new, between history and project, with near "Cultural Cantieri' set up in the nineties in the Ducrot archaeological industries, of the twentieth century, now at the center of the cultural events of the city of Palermo.

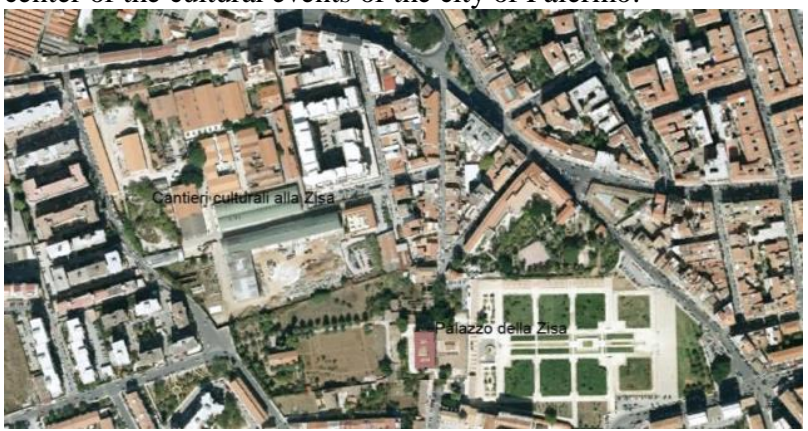

Figure 12. Aerial view fo the Zisa site.

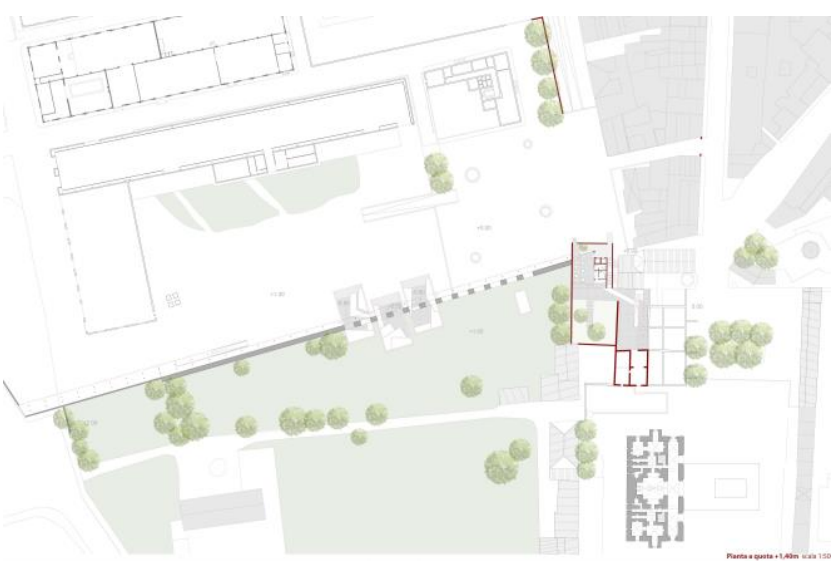

Figure 13. New relations between Zisa site and 'Cantieri culturali' area (Sferrazza, 2015)

\section{CURRENT STATUS AND PROPOSALS (A. Scianna)}

The construction of a modern information system on cultural heritage aimed at different needs of conservation and then the restoration and enhancement and real and virtual fruition requires a careful and deep study of the different heritage that may be subject to allocation in the system.

This is because despite the diversity of the goods has to constructive level in planimetric composition, style and architecture etc. you need to find the right key to configure a conceptual system that can describe the different objects.

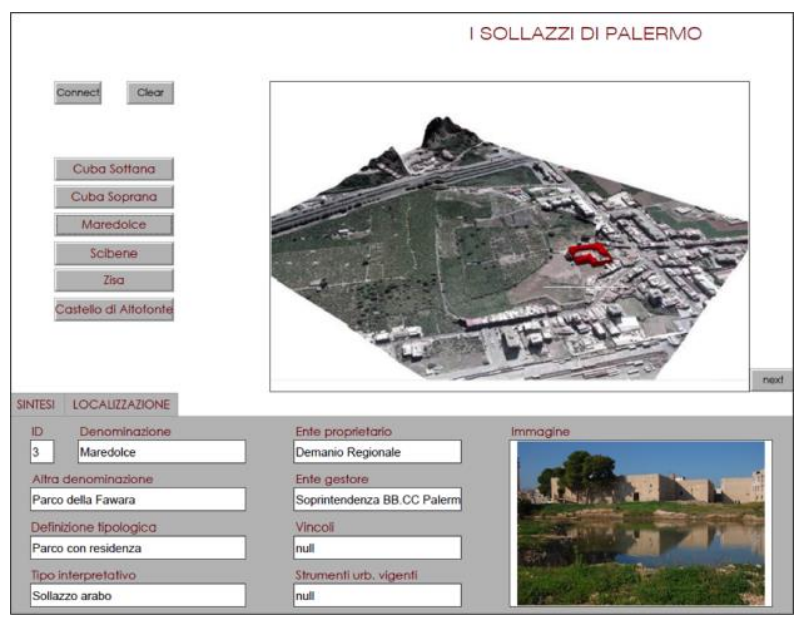

Figure 14. 3D Information system of Maredolce site (Gristina, Scianna, 2016)

The definition of a common language is a requirement that has always touched on all aspects of civil, social, economic of the population and it is absolutely necessary need in the field of computer science. To communicate with the computer systems or allow them to communicate with each other protocols and languages of communication have been developed. This occurred recently in the field of cultural heritage, but today the needs of an optimal retention of information that dematerialization impose new methods in these areas. As for the cultural heritage sector, as mentioned above, they have been developed for different proposals cataloging and at different levels of detail, for the most part based on consultation methods maybe a little 'outdated.

The current computer technology and the possibilities offered by HTML5 allow an alphanumeric access to information from the graphical display of a territorial context that is a path of which the cultural heritage are the waypoints, and starting this with successive zoom operations you can switch to a more detailed view of one of the cultural assets in order to obtain also information to a high level of detail.

The creation of a database that can productively support the preservation, restoration, enhancement and enjoyment requires real and virtual in a preliminary phase also an information survey both graphical and alphanumeric available, such as old profiling, but historical documents also topographic surveys conducted by conventional means. All these documents, even in an innovative concept of structuring and access to information system, will be integrated in order to give continuity to the evolutionary history of cultural and therefore the structuring of the information system well will also be conducted in compliance with that requirement.

In the workflow procedure for the implementation of an information system on cultural heritage, so it is important first to:

- Identify the different cultural heritage whose information will be stored in the database

- Carry out a survey of the wealth of knowledge available to every 
good

- choose the best mode of cultural development consultation

- Define a conceptual model that allows to completely describe all the assets to be managed

- define the level of detail for each of the cultural heritage in relation to the use and the available information content

- Define the building requirements of the IT system with particular regard to both the use of purpose that the type of users - study ways of structuring the database; this phase is central since it is necessary to adopt a structure that allows to reduce data redundancy and promote interoperability, reuse and expandability of the system and of the information content.

In addition to the "standard" information such as the location of the complex, the legal data or description of the installation, will be made particularly to the relationship with the context and the history of restoration, that particular historical process that allows us to understand the transformations of the twentieth century factory additions, alterations and interpolations, in relation to the ideas of the variables over time restoration (restoration, preservation, enhancement).

The need to document, through new media and technologies, cognitive type information for the management, enhancement and use of monuments, it is essential to optimize the cultural and communication with all audiences.

\section{CONCLUSIONS (R. Prescia)}

This situation suggests an urgent reflection on the relationship between history, representation and restoration in the past tightly integrated (Carbonara, 1997) and, more recently, distanced for the various university reforms for progressive educational specialization that perhaps now need to bring all interior of a recomposition of knowledge, which is useful to develop integrated knowledge programs, preservation and enhancement of monumental complexes such as those in question here. Moreover, in this sense they are structuring the ministerial actions of a systemic and integrated enhancement of cultural heritage, promoted since the enactment of the Code of cultural heritage that has made a significant conceptual shift from 'heritage of belonging' (State) to a ' use '(private).

The innovative technological importance, from the photogrammetric that with the 3D laser scanner, cannot ignore the integration with traditional beaded detail, as well as the return of the operator requires thorough history and restoration skills, as well as the still ' computer needs for its outstanding innovative design to compete with the contents to be transferred in its products, as well as recommend the latest Florence Declaration, Heritage and Landscape as human values (2014) that, by insisting on the value of 'traditional knowledge', invites you to guide the development of innovative instruments, within the objectives of their subject areas, precisely in order to avoid solipsistic advancement of knowledge in the technological sectors and not in conservation practices' (www.icomos.org).

All this leads to state insistently the need for a multidisciplinary and interdisciplinary approach to the problems of the assets that need concern through an innovative research method that does not mean, as it might seem, the renunciation of its know-how, but rather putting development of new operating procedures, resulting from the convergence of the areas of the edge of the individual disciplines.

\section{REFERENCES}

Agnello, F., Rilievo e rappresentazione del soffitto della navata centrale della cappella Palatina, in B. Brenk (a cura di), La cappella Palatina a Palermo, Modena 2010, pp. 295-352.

Agnello, F., Prescia, R., 2013 Integrated studies for the enhancement of complex historic monuments, in M. Boriani, con R.Gabaglio, D.Gulotta (a cura di), Built heritage 2013 - Monitoring conservation and management, Milan 18-20/11/13, online proceedings of the Conference, Politecnico di Milano, Milan, pp. 919-926

Bartolomucci, C., Nuovi metodi per la documentazione, in G. Carbonara, Trattato di restauro architettonico - II aggiornamento, Torino 2008, pp. 105-140.

Bettina Fiore, S., Le absidi della Cattedrale di Palermo tra rilievo, restauri e valorizzazione, tesi di laurea in Architettura, rel. Proff. F. Agnello, R. Prescia, Università di Palermo, A.A. 2011-12.

Buda, A., Il complesso di Maredolce tra conservazione $e$ valorizzazione, tesi di laurea in Architettura, rel. Prof. R. Prescia, Università di Palermo, A.A. 2011-12

Carbonara, G., Avvicinamento al restauro, Napoli 1997, pp. 467496.

Del Giudice, M., Descrizione al Tempio e monastero di S.Maria La Nova, Palermo 1702.

Genovese, C., Francesco Valenti. Restauro dei monumenti nella Sicilia del primo Novecento, Napoli 2010.

Gristina, S., Scianna, A., Tecnologie innovative per la conservazione e la fruizione del patrimonio culturale: una applicazione sperimentale GIS 3D sul Castello di Maredolce a Palermo, in R. Prescia, F. Trapani (a cura di), Rigenerazione urbana, innovazione sociale e cultura del progetto, Milano 2016, pp. 73-98. Lo Giudice, S., Il "libretto d'identità" dei beni culturali, in "Per rivista di Salvare Palermo", 7, 2003, pp. 14-15.

Lucchese, L., Torre Pisana nel Palazzo Reale di Palermo tra conoscenza e valorizzazione, tesi di laurea in Architettura, rel. Proff. F. Agnello, R. Prescia, Università di Palermo, A.A. 2011-12.

Montella, M., Toscano, B., Arte, comunicazione, valore: una conversazione (a cura di F. Coltrinari), in "Il capitale culturale", I 2010, pp. 149-161.

Monti, C., 1991 Nuove metodologie di rilievo e rappresentazione delle architetture, in R. A. Genovese (a cura di), Metodi classici e metodi ibridi nella documentazione del tessuto delle città storiche, atti del convegno nazionale (Napoli 27 giugno 1991), $\mathrm{n}^{\circ}$ monografico di "Restauro", 115-116, 1991, pp. 57-78.

Monti, C., 1993, La filosofia e la metodologia del rilievo architettonico moderno, in "Bollettino della società italiana di topografia e fotogrammetria", 1, gennaio-marzo, pp. 25-82

Neptis 2013 Progetto NEPTIS - Soluzioni ICT per la fruizione e l'esplorazione "aumentata" di Beni Culturali. Coordinatore Engineering Ingegneria Informatica S.p.A. Partecipanti: Università degli studi di Palermo, Università di Catania, Consiglio Nazionale delle Ricerche, PITecnoBio, IDS\&Unitelm. (PON R\&C 2007-13 Asse I Titolo III)

Prescia, R., Verso un nuovo 'Codice' dei beni culturali in Italia, in S. Valtieri (a cura di), Della bellezza ne è piena la vista! Restauro e conservazione alle latitudini del mondo nell'era della globalizzazione, Roma 2004, pp. 438-445.

Prescia, R., Il recupero del "paesaggio culturale" della Favara, in G. Barbera, P. Boschiero, L. Latini (a cura di), Maredolce-La Favara, Premio Internazionale Carlo Scarpa per il giardino, Palermo, Fondazione Benetton Studi Ricerche, Treviso 2015, pp. 128-134. Prescia, R. (a cura di), Valorizzazione e gestione delle informazioni, in D. Fiorani (coordinamento), RICerca/REStauro, atti del Convegno SIRA Roma 26-27settembre 16, vol. 4, Roma 2017.

Prescia, S., 1988 Il rilevamento metrico morfologico e la sua rappresentazione, in G. Aurigemma (a cura di), La Basilica Cattedrale di Cefalù. Materiali per la conoscenza storica e il restauro, vol. 8, Palermo.

Prescia, S., 1991 Sull'impiego dello strumento fotogrammetrico nella rappresentazione dei centri storici: esperienze siciliane, in R.A. Genovese (a cura di), metodi...cit., pp. 109-124.

Sferrazza, F., Il percorso dell 'acqua. Riqualificazione e connessione tra i Cantieri Culturali e la Zisa, tesi di laurea in Architettura, rel. 
Proff. G. Marsala, R. Prescia, Università di Palermo, A.A. 20145.

Tomaselli, F., Il ritorno dei Normanni, Roma 1994.

Trento, I., Zabbia, L., The arab-norman civil architecture in Palermo: enhancement strategies, in Heritage architecture landesign, focus on conservation regeneration innovation, "le vie dei mercanti", XI Forum internazionale di studi, a cura di C. Gambardella, Napoli (atti del congresso Aversa-Capri, 13-15 giugno 2013), pp. 890-898.
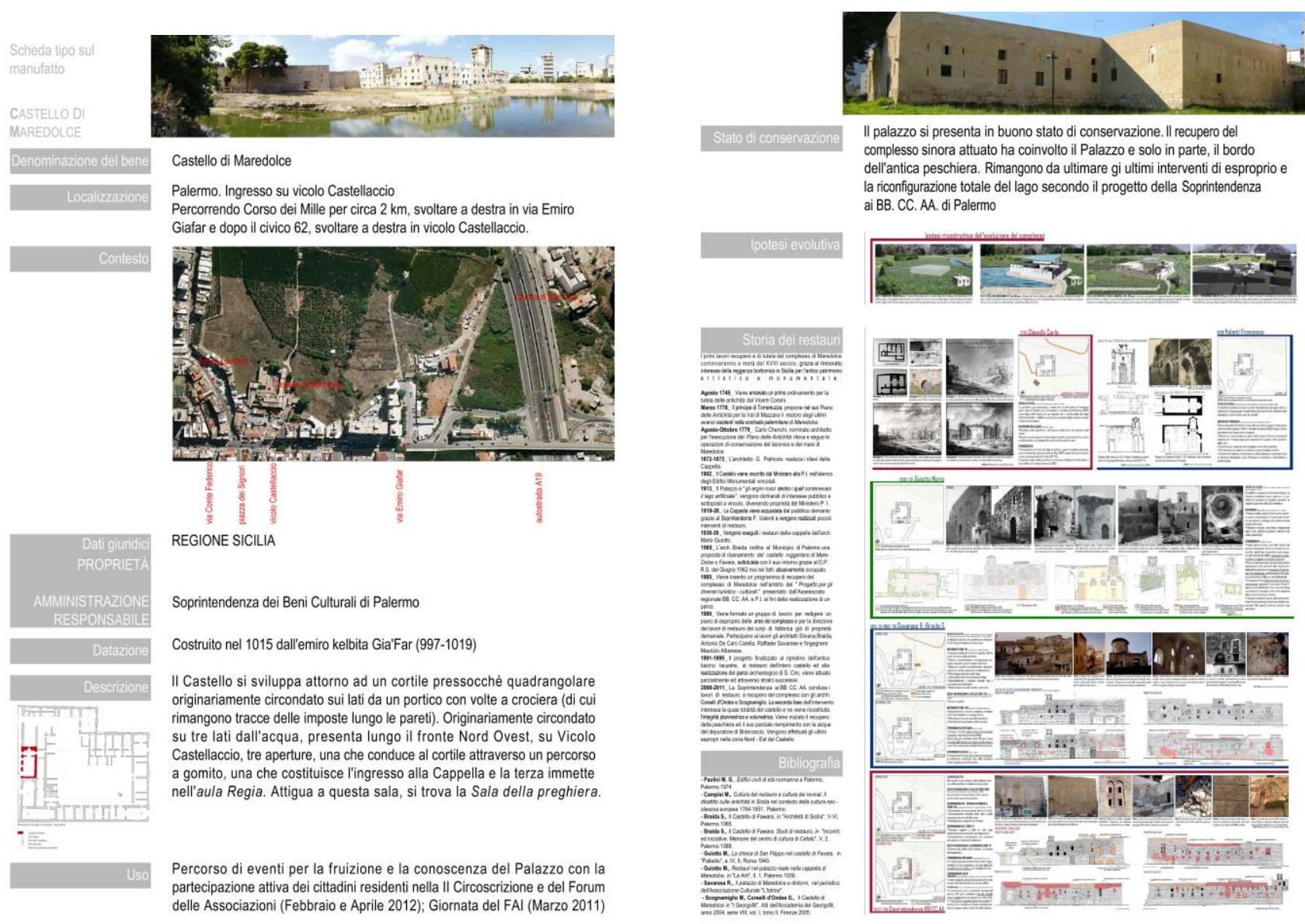

Annex. 1. Inventary sheet model. 